\title{
THE AFFIRMATIVE DOCTRINE OF MUTUALITY
}

The affirmative doctrine of mutuality has been stated thus: If one party to a contract is entitled to specific performance, so ipso facto is the other, for the equitable remedy if it exists at all must be mutual. ${ }^{x}$ The rule so stated would never allow a situation where one party would get specific performance, and yet the other party could not. But such situations exist and provide the basis for the well established doctrine of lack of mutuality. ${ }^{2}$ On the other hand, the affirmative doctrine has been denied altogether, and it has been urged that the true rationale where it has been seemingly applied is inadequacy of legal remedy. ${ }^{3}$ This explanation has been applied to those cases using the affirmative doctrine to justify decrees giving the purchase money to the vendor in contracts for the sale of personalty ${ }^{4}$ as well as of land.5 This denial of the doctrine fails to consider (a) the fact that the vendor is relieved of the necessity of showing inadequacy of legal remedy in jurisdictions applying the mutuality doctrine ${ }^{6}$

I Pomeroy, Specific Performance ( $3 \mathrm{~d}$ ed. 1926), $\$ \S 6,165$, cases cited; Williston, Contracts (I920), § I443; Clark, Is There a Positive Rule of Mutuality?, 3I Harv. L. Rev. 27I (Igx 7); Horack, Specific Performance for Purchase Price, x Ia. L. Bull. 53 (IgI5); Cogent v. Gibson, 33 Beav. 557 (1864); Raymond v. San Gabriel Valley Land and Water Co., 53 Fed. 883 (I893); Clark v. Cagle, I4I Ga. 703, 82 S.E. 21 (I914); Andrews v. Sullivan, 7 Ill. 327 (I845); Bumgardner v. Leavitt, 35 W.Va. I94, I3 S.E. 67 (I891); cases cited 36 Cyc. 565 .

2 The doctrine of lack of mutuality has various formulations reaching divergent results because of different limitations of the situations to which each is applicable. But each formulation when applied denies specific performance to a party otherwise entitled to it, for, it is said, the equitable remedy must be mutual. Fry, Specific Performance, (6th ed. I92I), $\S 460$ : "A contract to be specifically enforced by the court must, as a general rule, be mutual, - that is to say, such that it might, at the time it was entered into, have been enforced by either of the parties against the other." Ames, Lectures on Legal History (I9I3), 37x: "Equity will not compel specific performance by a defendant if, after performance, the common-law remedy of damages would be his sole security for the performance of the plaintiff's side of the contract." Cardozo, J. in Epstein v. Gluckin, 233 N.Y. 490, 494, I35 N.E. 86r (rg22): "What equity exacts to-day as a condition of relief is the assurance that the decree, if rendered, will operate without injustice or oppression either to plaintiff or defendant." See also Pomeroy, supra note I, $\$ 163,36$ Cyc. 629; Cook, The Lack of Mutuality Rule, 36 Yale L. Jour. 897 (I927); Stone, The Mutuality Rule in New York, I6 Col. L. Rev. 443 (Igr6).

As to the incompatibility of the two doctrines of mutuality as usually stated see Ames, $o p$. cit. 379; Clark, supra note I; Pomeroy, supra note $\mathrm{x}, \S \mathrm{I} 65$, n. (b).

3 Hodges v. Kowing, 58 Conn. I2, I8 Atl. 979 (1889); Eckstein v. Downing, 64 N.H. 248, 9 Atl. 626 (I887); Horack, supra note I; Lewis, A Vendor's Right to Specific Performance, 4I Am. L. Reg. (N.S.) 65 (r902); Walsh, Equity (r930), § 68.

4 Withy v. Cottle, x S. \& S. 174 (I822); Adderly v. Dixon, I S. \& S. 607 (1823); Cogent v Gibson, 33 Beav. 557 (I864); Bumgardner v. Leavitt, 35 W.Va. I94, I3 S.E. 67 (I89I); cases cited Pomeroy, supra note $\mathrm{x}, \$ \S 6, \mathrm{I65}$; cf. Baker Machinery Co. v. U.S. Fire Apparatus Co., Ix Del. Ch. 386, 97 Atl. 6r3 (rgr 5); Anderson v. Olsen, I88 Ill. 502, 59 N.E. 239 (I90I); Peck v. Beacon, 272 Ill. App. 424 (I933).

$s$ Walker v. Eastern Counties Ry. Co., 6 Hare 593 ( 1848 ); Raymond v. San Gabriel Valley Land and Water Co., 53 Fed. 883 (I893); Robinson v. Appleton, I24 Ill. 276 , I5 N.E. $76 \mathrm{r}$ (1888); cases cited Pomeroy, supra note I, \$\$ 6, I65.

${ }^{6}$ McClurg v. Crawford, 209 Fed. 340 (I9I3); Dollar v. Knight, $x_{45}$ Ark. 522, 224 S.W. 983 (rg20); Clark v. Cagle, $x_{4}$ r Ga. 703, 82 S.E. $2 x$ (rgr4). 
and (b) the continued use of the language of mutuality by the courts. ${ }^{7} \mathrm{Al}-$ though it is difficult to point to a case granting specific performance at the suit of one whose legal remedies are clearly shown to be adequate, ${ }^{8}$ it may be asserted fairly that there is an affirmative doctrine of mutuality. 9

But the affirmative mutuality doctrine as it exists differs from the broad statement of it in that it is only applied where one party is entitled to specific performance and the only possible objection to giving it to the other is adequacy of his legal remedy; for example, as in suits by the vendor for the purchase money. ${ }^{\text {I0 }}$ Its application has not extended to situations where some positive objection other than adequacy of legal remedy stands in the way of giving the remedy to the other party. Thus the mere fact that one party to a contract could get specific performance has not sufficed to give it to the other who is guilty of a fraud. Ix It does not apply where only one party has signed a memorandum sufficient for the statute of frauds; ${ }^{12}$ where one party is an infant who has since the making of the contract attained his majority ${ }^{; 3}$ where the state is a

7 The influence of the mutuality doctrine is shown by the fact that specific performance has been decreed for the vendor in a contract for the sale of land where he held notes for the purchase money. Andrews v. Sullivan 7 Ill. 327 (1845); Burger v. Potter, $3_{2}^{2}$ Ill. 66 (1863).

${ }^{8}$ Horack, supra note $\mathrm{r}$, suggests a contract for the sale of a second-hand watch having belonged to defendant's father would furnish a test case for the mutuality doctrine. The very fact, however, that the watch is second-hand would be likely to make market value in this case no more than a concept, thus allowing the contention that the vendor's legal remedy is inadequate because damages are conjectural. Cf. 25 Mich. L. Rev. 546 (I927). A better test would be a contract for the sale of a commodity with an open market, as cotton, desired by the purchaser for some sentimental reason, as its having been grown on an historic battlefield. Though the purchaser's legal remedy is inadequate, such cotton being unique, the vendor can sell it at market price and with damages recoverable at law get everything he bargained for.

9 Clark, stupra note $\mathrm{r}$; Ames explains the affirmative mutuality doctrine: "The vendor, from the time of the bargain, holds the legal title as a security for the payment of the purchase money, and his bill is like a mortgagee's bill for payment and foreclosure of the equity of redemption." Ames, supra note 2, 380. For criticism of Ames' view see Clark, supra note I; Williston, supra note I, § I443.

The Contracts Restatement ( 1932$), \S 372(2)$, states the affirmative rule thus: "The fact that the remedy of specific performance is available to one party to a contract is not in itself a sufficient reason for making the remedy available to the other; but it is of weight when it accompanies other reasons, and it may be decisive when the adequacy of damages is difficult to determine and there is no other reason for refusing specific performance."

${ }^{10}$ Cases, supra note 7. Durfee, Mutuality in Specific Performance, 20 Mich. L. Rev. 289 (1922), states the affirmative doctrine: "Complainant, although he had an adequate remedy at law should be given relief if . . . . the other party would have been entitled to relief (provided there was no affirmative objection to the relief sought in the case before the court such as impossibility of compelling performance.)"

${ }^{11}$ Ames, supra note I, 373; Williston, supra note $\mathrm{I}$, $\S \S \mathrm{r} 435,1525$.

${ }^{2}$ Hodges v. Kowing, 58 Conn. I2, I8 Atl. 979 (r889); Ames, supra note I, 373; Williston, supra note I, § 1437. But see Duvall v. Meyers, 2 Md. Ch. 401 (1850).

${ }_{33}$ Clayton v. Ashdown, 9 Vin. Abr. 393 (I7r4); note, 43 A.L.R. x20; Ames, supra note I, 374; Williston, sutpra note $1, \S \mathrm{r}_{438} 8$. 
party $;^{14}$ and where the purchaser has become bankrupt; $;^{15}$ frequently it has been held not to apply in bilateral contracts between fiduciary and principal. ${ }^{16}$ Nor has the fact that one party is entitled to specific performance been a reason for decreeing specific performance of personal service contracts ${ }^{\text {I7 }}$ or contracts the supervision of which the court believes too difficult to undertake $;^{{ }^{8}}$ in such situations the negative rule is more likely to be invoked to deny specific performance to either party.

It has been stated by eminent authority that after conveyance the vendor is not entitled to specific performance. ${ }^{\text {I9 }}$ It would seem, prima facie, that under the formulation of the affirmative doctrine submitted, there is no other objection to specific performance for a vendor who has conveyed except the adequacy of his legal remedy, and that therefore he should be entitled to specific performance unless the rule here given is inaccurate. But it should be pointed out that no case has expressly refused the equitable remedy to a vendor who has conveyed on the grounds that to do so would be inconsistent with the affirmative mutuality rule. Jones v. Nerwhall,,$^{20}$ the only case cited to support the proposition that a vendor cannot get specific performance after he has conveyed, ${ }^{2 x}$ based its decision on the ground that the inadequacy of legal remedy provision in the Massachusetts statute makes it impossible to accept the affirmative doctrine of mutuality. And the objection to giving the vendor specific performance in such a case is not merely that the legal remedy is adequate but that it is practically identical with the equitable remedy, since nothing remains to be done under the contract but the payment of the purchase money.22 Equity might well decline to exercise its jurisdiction to enforce a contract where it does just what is done at law.

${ }^{4}$ State Highway Comm. v. Golden, II 2 N.J.Eq. I56, I63 Atl. 55I (1933).

"s Contracts Restatement (1932), \$ 372, example 2.

${ }^{16}$ Ex parte Lacey,6 Ves.625 (1802); Ames, supra note $\mathrm{r}, 373$; Williston, supra note $\mathrm{I}, \S$ I 435 .

${ }^{17}$ Cases denying specific performance to a party otherwise entitled to it because of the lack of mutuality doctrine are in point here, because if the affirmative doctrine is applied, both parties would be entitled to specific performance. Pickering v. Bishop of Ely, 2 Y. \& C.C.C. 249 ( I 843); Heth v. Smith, I 75 Mich. 328, I4I N.W. 583 (r913); cases cited Pomeroy, supra note $1, \$ 164$.

${ }^{18}$ Johnston v. Ry. Co., 3 D.G.M. \& G. 913 (1853); Pac. Ry. Co. v. Campbell-Johnston, I 53 Cal. I06, 94 Pac. 623 (Igc8); cases cited Pomeroy, supra note I, $\S$ I64. $\S 1443$.

I9 Contracts Restatement (I932), $\$ 360$; Ames, supra note I, 380; Williston, supra note I,

${ }^{20}$ II 5 Mass. 244 (1874).

${ }^{21}$ The contract provided for the sale of shares in two land companies to be paid for in installments. The first four installments were designated as payment for the shares in one company, the last installments for the other. After the shares in one company had been paid for and transferred, the defendant refused to pay for the others. It was held the plaintifi was not entitled to specific performance because at law he could sue for the installment due, and that is precisely what he could get at equity.

${ }_{22}$ Contracts Restatement (1932), § 360, comment (e); Williston, supra note I, § I443: "All of these results would be sufficiently explained by saying that where the legal remedy secured not only adequate redress, but practically identical redress with that which could be given by equity, equity will decline jurisdiction." 
Where neither party to a contract has signed a memorandum sufficient for the statute of frauds, but one party has done sufficient acts of part performance to entitle him to equitable relief, there is an affirmative objection other than adequacy of legal remedy to giving the other party specific performance, namely the statute of frauds. Thus, though language can be found in favor of applying the mutuality rule here, ${ }^{23}$ it seems preferable to hold that the plaintiff must bring himself within the reason for the rule of part performance. He would have to show an irreparable change of position induced by the agreement, i.e., "equitable fraud," depending on the requirements of the jurisdiction. But specific performance may be granted because the acts of the other person constitute part performance, for the defendant's taking possession can be unequivocally referable to a contract, ${ }^{27}$ and his acts, such as cutting the timber, may cause the plaintiff an irreparable change of position, ${ }^{28}$ but this is based on considerations entirely different than mutuality.

The formulation of the affirmative doctrine here submitted does not conflict with the negative doctrine of mutuality which, regardless of how formulated, has never been used to deny the equitable remedy merely because adequacy of legal remedy might be an objection to specific performance. Thus a purchaser has never been denied specific performance merely because his vendor's legal remedy might be adequate..$^{29}$ Where the negative doctrine is invoked to deny specific performance to a plaintiff otherwise entitled to it, the objection to equitable relief on the defendant's part is some positive objection other than adequacy of legal remedy, such as plaintiff's being an infant, ${ }^{30}$ compulsion of personal services, ${ }^{3 x}$ or difficulty of supervision..$^{32}$

SIDNEY ZATZ

${ }^{23}$ Sweeney v. O'Hara, 45 Ia. 34 (I876); Clark, supra note I; Clark, Equity (19I9), § I32. The authorities cited by him do not necessarily support his proposition.

${ }^{24}$ Burns v. Daggett, I4I Mass. 368, 6 N.E. 727 (I886); Williams v. Carty, 205 Mass. 398, 9 I N.E. 392 (I9I0); Slingerland v. Slingerland, 39 Minn. I97, 39 N.W. I46 (I888); 32 Yale L. Jour. 89 (I922).

${ }_{25}$ Kine v. Balfe, 2 Ball \& B. 343 ( $18 \mathrm{x}_{3}$ ); Bradley v. Loveday, 98 Conn. $3 \mathrm{I}_{5}$, II9 Atl. I47 (r922); Pomeroy, supra note I, § I08a; 32 Yale L. Jour. 846 (Ig23).

${ }^{26}$ Maddison v. Alderson, L.R. 8 App. Cas. 467 ( 1883 ); Burns v. McCormick, 233 N.Y. 230, 135 N.E. 273 (1922).

${ }^{27}$ Kine v. Balfe, 2 Ball \& B. 343 (1813); Price v. Hart, 29 Mo. I7x (I859); Morphett v. Jones, I Swans. I72, I8I (I8I8).

${ }^{28}$ In re Fay, 213 Pa. St. 428, 62 Atl. 99I (r906); Latom v. Brooker, 5 I Mo. ${ }_{4} 8$ (I872); Chambers v. Row, 36 Ill. I7I (I864); compare Pomeroy, supra note I, § I05. Where mere possession by defendant is sufficient part performance, the giving up of possession by the plaintiff should be part performance. Kine v. Balfe, 2 Ball. \& B. 343 (1813); Pyke v. Williams, 2 Vern. Ch. 455 ( 1703 ); Howard v. Patent Ivory Co., 38 Ch. Div. ${ }_{5} 6$ (I888); Earl of Aylesford's Case, 2 Strange 783 (I727).

29 Even Ames' statement of the negative rule does not consider this. See supra note 2. For a statement of the negative rule that does consider this see 27 Yale L. Jour. 26I (1917).

${ }^{30}$ Flight v. Bolland, 4 Russ. 298 (I829); note 43 A.L.R. I20; but see Seaton v. Tohill, II Colo. App. 211, 53 Pac. $x 70$ (1898).

${ }^{3 r}$ See note I 7 supra.

${ }^{32}$ See note I8 supra. 